Eur J Clin Chem Clin Biochem

1995; 33:211-219

(c) 1995 Walter de Gruyter \& Co. Berlin · New York

\title{
Extracellular Matrix Proteins as Early Markers in Diabetic Nephropathy ${ }^{1}$ )
}

\author{
By Irmtrnıd Jäckle-Meyer ${ }^{1}$,Borika Szukics', Kerstin Neubauer ${ }^{1}$, Vera Metze ${ }^{1}$, Rïdiger Petzoldt ${ }^{2}$ and Hilmar Stolte ${ }^{1}$ \\ 1 Arbeitsbereich Experimentelle Nephrology, Abteilung für Nephrologie, Zentrum für Innere Medizin und Dermato- \\ logie, Medizinische Hochschule Hannover, Hannover, Germany \\ 2 Herz- und Kreislaufzentrum Nordrhein-Westfalen, Bad Oeynhausen, Germany
}

(Received June 2, 1994/January 31, 1995)

Summary: Basement membrane thickening and mesangial expansion characterize the renal involvement in diabetes mellitus and precede any symptoms of renal dysfunction, e.g., albuminuria and changes in glomerular filtration rate. Since the morphological changes can only be diagnosed by biopsy, this study was designed to investigate whether the urinary excretion of renal extracellular matrix proteins might reflect the morphological alterations.

To specify the extent of renal involvement in diabetes, the patients, type I as well as type II diabetics, were classified according to their urinary albumin excretion: normal albumin excretion below $30 \mu \mathrm{g} / \mathrm{min}$, microalbuminuria from 30 to $300 \mu \mathrm{g} / \mathrm{min}$, and overt albuminuria above $200 \mu \mathrm{g} / \mathrm{min}$. Laminin, collagen IV, and fibronectin, all intrinsic components of the renal extracellular matrix, were determined in serum and urine by radioimmunoassay or enzymelinked-immunosorbent-assay, respectively. The results are given as median values ( $\tilde{x})$. Additionally, the urinary fragment pattern of fibronectin was analysed qualitatively by immunoblotting.

Laminin concentrations in serum and in urine did not change in diabetics. Collagen IV decreased in serum of patients with increased albumin excretion (controls: $\tilde{\mathrm{x}}=255 \mu \mathrm{g} / \mathrm{l}$, normoalbuminuric patients: $\tilde{\mathrm{x}}=56 \mu \mathrm{g} / \mathrm{l}$, microalbuminuric patients: $\tilde{\mathrm{x}}=52 \mu \mathrm{g} / \mathrm{l}$, and patients with overt albuminuria: $\tilde{\mathrm{x}}=70 \mu \mathrm{g} / \mathrm{l} ; \alpha<0.01$ ) and increased in urine (controls, normoalbuminuric and microalbuminuric patients: not detectable, patients with overt albuminuria: $\tilde{\mathrm{x}}=5 \mathrm{ng} / 12 \mathrm{~h} ; \alpha<0.001$ ). Fibronectin was elevated in serum (controls: $\tilde{\mathrm{x}}=355 \mathrm{mg} / \mathrm{l}$; normoalbuminuric patients: $\tilde{\mathrm{x}}=640 \mathrm{mg} / \mathrm{l}$, microalbuminuric patients: $\tilde{\mathrm{x}}=710 \mathrm{mg} / \mathrm{l}$, and patients with overt albuminuria: $\tilde{\mathrm{x}}=630 \mathrm{mg} / \mathrm{l}$; $\alpha<0.0001$ ) and in urine, even in patients with normal albumin excretion (controls: $\tilde{x}=16.8 \mu \mathrm{g} / 12 \mathrm{~h}$, normoalbuminuric patients: $\tilde{\mathrm{x}}=121 \mu \mathrm{g} / 12 \mathrm{~h}$, microalbuminuric patients: $\tilde{\mathrm{x}}=108 \mu \mathrm{g} / 12 \mathrm{~h}$, patients with overt albuminuria: $\tilde{\mathrm{x}}=186 \mu \mathrm{g} / 12 \mathrm{~h} ; \alpha<0.01$ ). The urinary fragment pattern of fibronectin, consisting of two main bands of a relative molecular mass of $M_{\mathrm{r}} 75.000$ and 45000 , was not altered in controls and diabetics. Type I and type II diabetic patients did not show significant differences in any quantities tested.

It was shown in this study that the determination of laminin and collagen IV in serum and urine gave no information exceeding the routinely used quantities of kidney function. But the renal fibronectin excretion was elevated before any functional changes occurred. It was concluded that this might be indicative of the early mesangial expansion in diabetes mellitus. The determination of urinary fibronectin could therefore probably serve as a more sensitive marker for renal involvement in diabetes mellitus than microalbuminuria or changes in glomerular filtration rate.

1) Supported by the Deutsche Forschungsgemeinschaft Sto 71/6-1 and Sto $71 / 6-2$ and the Commission of the European Community in the framework of the programme STEP (Science and Technology of Environment Protection). 


\section{Introduction}

About $45 \%$ of type I diabetic patients develop overt diabetic nephropathy in the course of their disease. One quarter of all new cases of uraemia are due to this diabetic complication (1). These facts underscore the necessity of carefully monitoring kidney function in diabetic patients. Microalbuminuria is currently the first sign that may indicate an incipient diabetic nephropathy. Approximately $80 \%$ of younger diabetic patients and $20 \%$ of elder patients with microalbuminuria progress to overt 'diabetic nephropathy (2). However, before microalbuminuria can be diagnosed, morphological alterations in the kidney, such as basement membrane thickening and mesangial expansion, occur (3). Maurer et al. (4) demonstrated that mesangial expansion especially correlates with the clinical manifestation of diabetic nephropathy.

The morphological alterations are due to changes in the metabolism, composition and integrity of the renal extracellular matrix induced by the metabolic disorders in diabetes (5). It was demonstrated that in mild to moderate diabetic nephropathy laminin, collagen IV, and fibronectin accumulate in the glomerular extracellular matrix $(6-8)$, while the amount of these structural proteins within the glomerular apparatus is drastically reduced in the advanced stage of the disease coinciding with glomerular sclerosis $(6,7)$. Further, the decrease of sulphated proteoglycans in the glomerular basement membrane in diabetes leads to the loss of the charge selectivity, and consequently to glomerular proteinuria (9).

To date, the morphological alterations can only be diagnosed by biopsy and subsequent immunohistochemistry or electronmicroscopy. Since these methods are not indicated in monitoring the state of the kidney in diabetic patients, the question arises whether the changes in the renal extracellular matrix might be reflected by an altered excretion of the relevant proteins in final urine. Little is known about the urinary excretion of structural proteins. Weil et al. (10) described a decreased excretion of "glomerular basement membrane-like protein" in the urine of diabetic rats. Mellon et al. (11) and Torffuit et al. (12) found an increased collagen IV excretion in congenitally diabetic mice and in men with progressing albumin excretion, respectively.

Therefore, the aim of the present study was to investigate the relevance of the urinary excretion of extracellular matrix proteins, especially in the early phases of renal involvement in diabetes mellitus. Collagen IV, laminin, and fibronectin as the major intrinsic components of the glomerular basement membrane and the mesangial matrix were determined in the urine of type I and type II diabetic patients without any symptoms of diabetic nephropathy and at different stages of this disease.

\section{Patients and Methods}

\section{Subjects}

In this trial 86 in-patients of a Diabetes Hospital with type I diabetes (insulin-dependent; $n=34$ ) and type II diabetes (non-insulin dependent, $n=52$ ) were examined. To be included in this study, the patients had to have a known history of diabetic nephropathy or no symptoms of renal involvement in diabetes. Subjects with a renal disease different from diabetic nephropathy, benign or malignant tumours, inflammatory processes, recent surgery, and pregnant women were excluded from this study. The detailed clinical data on the patients are listed in table 1. Type I diabetics received insulin injections. Nineteen type II diabetics were treated with oral sulphonylurea antidiabetics (glibenclamide, Euglucon ${ }^{\circledR}$; glipizide, Glibenese $\left.{ }^{\circledR}\right), 18$ with insulin, 10 with a combination of both, while 5 had no therapy with antidiabetic agents.

Twenty-one normotensive, healthy volunteers (10 males, $11 \mathrm{fe}$ males) ranging in age from 23 to 81 years served as control persons.

From each patient and from the healthy control persons 12-hours urine specimens were collected $(8: 00$ p. m. to $8: 00$ a.m.). Additional serum samples were obtained after overnight fasting. Aliquots of serum and urine were combined with $10 \mu$ proteinase inhibitor solution per $\mathrm{ml}$ sample $(0.1 \mathrm{~mol} / \mathrm{l}$ phenyl-methyl-sulphonyl-fluoride in dimethylsulphoxide; Sigma Chemicals, St. Louis, $\mathrm{MO}, \mathrm{USA}$ ) and stored at $-20^{\circ} \mathrm{C}$ for further use.

\section{Quantities measured in general}

Endogenous creatinine clearance was determined by measuring serum and urine creatinine with an automated creatinine analyzer (Model R2, Beckman Instruments $\mathrm{GmbH}$, Munich, Germany). Glucose was analysed with a commercially available test kit (Boehringer, Mannheim, Germany) and total urinary protein according to Bradford (13). Urinary albumin was determined by rocket-immuno-electrophoresis (14). Anti-human-albumin antibodies and purified human albumin were purchased from Behring Werke AG (Marburg, Germany). $\mathrm{HbA}_{\mathrm{lc}}$ was measured as described by Cole et al. (15).

Tab. 1 Clinical data on the diabetic patients (medians and ranges)

\begin{tabular}{|c|c|c|c|c|}
\hline \multirow[b]{2}{*}{$\begin{array}{l}\text { No. of patients } \\
(\delta / \%)\end{array}$} & \multicolumn{2}{|c|}{ Type I } & \multicolumn{2}{|c|}{ Type II } \\
\hline & 34 & $(20 / 14)$ & 52 & $(27 / 25)$ \\
\hline Age (a) & 40 & $(18-83)$ & 51 & $(32-80)$ \\
\hline $\begin{array}{l}\text { Diabetes duration } \\
\text { (a) }\end{array}$ & 15 & $(0-44)$ & 13 & $(1-41)$ \\
\hline $\begin{array}{l}\text { Blood glucose } \\
(\mathrm{mmol} / \mathrm{l})\end{array}$ & 8.4 & $(1.5-22.0)$ & 7.2 & $(2.2-19.9)$ \\
\hline $\mathrm{HbA}_{1 \mathrm{c}}(\%)$ & 10.1 & $(7.0-14.5)$ & 11.3 & $(6.4-14.3)$ \\
\hline $\begin{array}{l}\text { Systolic blood } \\
\text { pressure }(\mathrm{mmHg})\end{array}$ & 120 & $(100-180)$ & 125 & $(90-180)$ \\
\hline $\begin{array}{l}\text { Diastolic blood } \\
\text { pressure }(\mathrm{mmHg})\end{array}$ & 70 & $(60-110)$ & 80 & $(50-100)$ \\
\hline Retinopathy & 21 & & 14 & \\
\hline Neuropathy & 10 & & 9 & \\
\hline Angiopathy & 2 & . & 3 & \\
\hline
\end{tabular}




\section{Quantitative determination of extracellular matrix} proteins

Laminin-Pl-fragment in serum and urine was quantified with a commercially available radioimmuno-assay (Behring Werke $A G$, Marburg, Germany).

Collagen IV in serum and urine was analysed by a sandwich-enzyme-linked-immunosorbent-assay. Specific antibodies were raised in rabbits against human placental collagen IV (Sigma chemicals, St. Louis, MO, USA) and purified by affinity chromatography on Protein-A-Sepharose (Pharmacia-LKB, Uppsala, Sweden). To measure collagen IV concentrations, high affinity flat-bottom microtitre plates (Greiner, Nürtingen, Germany) were coated with anti-collagen IV antibodies, diluted $1: 200$ in coating buffer (15

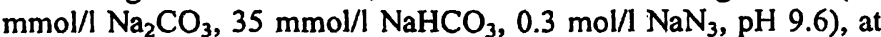
$+4{ }^{\circ} \mathrm{C}$ overnight. Remaining free binding sites on the plastic surface were blocked with $2 \mathrm{~g} / \mathrm{l}$ bovine serum albumin in phosphate buffered saline $\left(0.15 \mathrm{mmol} / 1 \mathrm{NaCl}, 8 \mathrm{~mol} / 1 \mathrm{Na}_{2} \mathrm{HPO}_{4}, 3 \mathrm{mmol} / 1\right.$ $\mathrm{KCl}, 1.5 \mathrm{mmol} / 1 \mathrm{KH}_{2} \mathrm{PO}_{4}, 0.3 \mathrm{~mol} / 1 \mathrm{NaN}_{3}, 0.5 \mathrm{ml} / 1$ Tween $20, \mathrm{pH}$ 7.4). Thereafter, urine and serum samples were incubated in parallel with the collagen IV standards (human placental collagen IV; Sigma Chemicals, St. Louis, MO, USA) in a serial dilution from 1 to $2500 \mu \mathrm{g} / \mathrm{l}$ in phosphate buffered saline. Bound antigens were detected with the same anti-collagen IV antibody used in the first step, but now coupled to alkaline phosphatase (dilution $1: 1000$ in phosphate buffered saline). Visualization of the bound antibody was achieved by the enzymatic reaction of alkaline phosphatase with $1 \mathrm{~g} / 1 \mathrm{p}$-nitrophenylphosphate (Sigma Chemicals, St. Louis, MO, USA) in substrate buffer ( $1 \mathrm{~mol} / 1$ diethanolamine, $0.5 \mathrm{mmol} / 1$ $\mathrm{MgCl}_{2} \times 6 \mathrm{H}_{2} \mathrm{O}, \mathrm{pH}$ 9.8). The concentration of the coloured reaction product was measured at $405 \mathrm{~nm}$ (Titertek Multiskan Photometer, Flow Laboratories, McLean, VA, USA). Between each incubation step microtitre plates were rinsed 5 times with phosphate buffered saline (Titertek Microplate Washer S8/12, Flow Laboratories, McLean, VA, USA). Alkaline phosphatase (Type VII from bovine intestinal mucosa; Sigma Chemicals, St. Louis, MO, USA) was conjugated to the antibodies by the one-step glutaraldehyde method described by Avrameas (16).

The inter-assay coefficient was $12 \%$ and the intra-assay coefficient was $10 \%$. Cross reactions with other collagen types and structural proteins such as laminin and fibronectin could not be observed.

Total fibronectin was determined with a sandwich-enzyme-linkedimmunosorbent-assay (17). Anti-human plasma fibronectin was purchased from Dako AS (Copenhagen, Denmark) and purified human plasma fibronectin from Sigma Chemicals (St. Louis, MO, USA). Conjugation of alkaline phosphatase to the anti-fibronectin antibody was also performed as described by Avrameas (16).

\section{Immunoblotting of fibronectin}

The urinary proteins were separated in a $5-16 \%$ sodium dodecylsulphate-polyacrylamide gradient gel prior to the blotting procedure. Slabgels were prepared on GelBond PAG films $(125 \times 260$ $\mathrm{mm}$; Pharmacia LKB, Uppsala, Sweden), in a gel casting chamber, $125 \times 260 \times 0.5 \mathrm{~mm}$ (Pharmacia LKB, Uppsala, Sweden). The running gel was prepared of equal volumes of dense acrylamide solution (160 g/l acrylamide, $3 \mathrm{~g} / \mathrm{l}$ bis-acrylamide; $170 \mathrm{~g} / \mathrm{l}$ sucrose, $1 \mathrm{~g} / 1$ sodium dodecylsulphate, $0.4 \mathrm{ml} / 1$ tetramethylene diamine, 0.4 $\mathrm{g} / \mathrm{l}$ ammonium persulphate in $0.4 \mathrm{~mol} / \mathrm{h}$ Tris $\mathrm{HCl}$ buffer, $\mathrm{pH} 8.6$ ), and light solution (50 $\mathrm{g} / 1$ acrylamide, $2 \mathrm{~g} / \mathrm{l}$ bis-acrylamide; $1 \mathrm{~g} / 1$ sodium dodecylsulphate, $0.4 \mathrm{ml} / 1$ tetramethylene diamine, $0.4 \mathrm{~g} / 1$ ammonium persulphate in $0.4 \mathrm{~mol} / \mathrm{h}$ Tris $\mathrm{HCl}$ buffer, $\mathrm{pH} 8.6$ ), mixed with a gradient former. The stacking gel was composed as follows: $50 \mathrm{~g} / 1$ acrylamide, $0.2 \mathrm{~g} / 1$ bis-acrylamide, $0.8 \mathrm{~g} / 1$ sodium dodecylsulphate, $0.8 \mathrm{ml} / 1$ tetramethylene diamine, $0.8 \mathrm{~g} / 1$ ammonium persulphate in $0.06 \mathrm{~mol} / 1$ Tris $\mathrm{HCl}$ buffer, $\mathrm{pH} 6.8$.

Samples were combined with equal volumes of sample buffer (10 $\mathrm{ml} / 1$ glycerol, $20 \mathrm{~g} / 1$ sodium dodecylsulphate, $10 \mathrm{ml} / 1$ mercaptoethanol in $75 \mathrm{mmol} / \mathrm{l}$ Tris $\mathrm{HCl}$ buffer, $\mathrm{pH} \mathrm{6.8)}$. They were heated at $95^{\circ} \mathrm{C}$ for $10 \mathrm{~min}$, alkylated with $10 \mathrm{~g} / 1$ iodoacetic acid, and heated again for $20 \mathrm{~min}$ at $95^{\circ} \mathrm{C}$. Bromophenol blue was used as front marker. Molecular mass standard (biotinylated SDS-PAGE standard, low range and high range, Biorad, Richmond, CA, USA) and purified plasma fibronectin were run in parallel.

A buffer containing $25 \mathrm{mmol} / \mathrm{l}$ Tris $\mathrm{HCl}$, and $200 \mathrm{mmol} / \mathrm{l}$ glycine, $\mathrm{pH} 8.6$, was used for electrophoresis, which was performed in a Multiphor II Electrophoresis Unit (Pharmacia LKB, Uppsala, Sweden) at $+5^{\circ} \mathrm{C}$ for $30 \mathrm{~min}$ at $20 \mathrm{~mA}$ and then for $2.5 \mathrm{~h}$ at $30 \mathrm{~mA}$.

Proteins were transferred onto nitrocellulase (Transfer Membrane Immobilon $\mathrm{P}$, pore size $0.45 \mu \mathrm{m}$; Millipore Corporation, Bedford, MA, USA) after electrophoresis by semidry-blotting (Sartoblot-II$\mathrm{S}$, Sartorius, Göttingen, Germany) in a discontinuous buffer system (18). The protein transfer was performed at $1.5 \mathrm{~mA} / \mathrm{cm}^{2}$ for 45 $\mathrm{min}$. Thereafter, nitrocellulose was incubated in $20 \mathrm{~g} / \mathrm{l}$ casein in phosphate buffered saline $\left(140 \mathrm{mmol} / \mathrm{l} \mathrm{NaCl}, 1.5 \mathrm{mmol} / 1 \mathrm{KH}_{2} \mathrm{PO}_{4}\right.$, $10 \mathrm{mmol} / 1 \mathrm{Na}_{2} \mathrm{HPO}_{4}, 2.5 \mathrm{mmol} / 1 \mathrm{KCl}, 0.3 \mathrm{~mol} / 1 \mathrm{NaN}_{3}, \mathrm{pH}$ 8.2) for 1 hour at $37^{\circ} \mathrm{C}$. The immunologic reactions were performed with appropriate antibodies diluted in $2 \mathrm{~g} / \mathrm{l}$ casein, and $0.5 \mathrm{ml} / \mathrm{l}$ Tween 20 in phosphate buffered saline. The following detection system was used for the detection of urinary fibronectin: anti-human-fibronectin-antibodies (diluted 1:4000; incubation: 1 hour at $37^{\circ} \mathrm{C}$ ), biotinylated anti-rabbit-IgG-antibodies (diluted 1:2000: incubation: 1 hour at $37^{\circ} \mathrm{C}$ ), streptavidin coupled to alkaline phosphatase (diluted 1:2000; incubation: 1 hour at $37^{\circ} \mathrm{C}$ ). All antibodies were purchased from Dako AS (Copenhagen, Denmark). Nitrocellulose was rinsed five times for $5 \mathrm{~min}$ with phosphate buffered saline between each incubation step. The bound antibodies were visualized by the enzymatic reaction of the coupled alkaline phosphatase as described by Blake et al. (19).

\section{Statistical analysis}

For statistical analysis, the correlation coefficient was determined and the Mann-Whitney test for independent samples was used. The level of significance was defined as $\alpha=0.05$.

\section{Results}

\section{Quantities measured in general}

Currently, the determination of the urinary albumin excretion is the best method to identify patients with a high risk of diabetic nephropathy, since microalbuminuria (urinary albumin excretion $>20-70 \mu \mathrm{g} / \mathrm{min}$ ) is predictive of the development of this diabetic complication. The aim of the present study was to evaluate whether the urinary excretion of extracellular matrix proteins gives additional information about the renal involvement in diabetes. The diabetic patients included in this study were therefore grouped according to their urinary albumin excretion. Diabetics with normal urinary albumin excretion below $30 \mu \mathrm{g} / \mathrm{min}$, with microalbuminuria (urinary albumin excretion $30-200 \mu \mathrm{g} / \mathrm{min}$ ), and with overt albuminuria (urinary albumin excretion above $200 \mu \mathrm{g} / \mathrm{min}$ ) were differentiated. In table 2 the functional quantities such as creatinine clearance, total urinary protein excretion, and urinary albumin excretion determined for the patients and the control persons are given. With regard to these quantities no significant differences between type I and type II diabetics could be found within the three groups of diabetics. 
Tab. 2 Functional quantities of the diabetic patients and of the controls (median and ranges).

The differences between type I and type II diabetic patients are not significant in the different groups.

\begin{tabular}{|c|c|c|c|c|c|}
\hline \multirow[b]{2}{*}{ Controls $(n=21)$} & \multirow{2}{*}{$\begin{array}{l}\begin{array}{l}\text { Creatinine clearance } \\
\left(\mathrm{ml} / \mathrm{min} \times 1.73 \mathrm{~m}^{2}\right)\end{array} \\
109(85-168)\end{array}$} & \multicolumn{2}{|c|}{$\begin{array}{l}\text { Total urinary protein } \\
(\mathrm{mg} / 12 \mathrm{~h})\end{array}$} & \multicolumn{2}{|c|}{$\begin{array}{l}\text { Urinary albumin } \\
(\mathrm{mg} / 12 \mathrm{~h})\end{array}$} \\
\hline & & 31.2 & $(1.5-52.5)$ & 5.53 & $(0.56-16.92)$ \\
\hline \multicolumn{6}{|c|}{ Diabetic patients with normal albumin excretion $(<30 \mu \mathrm{g} / \mathrm{min})$} \\
\hline $\begin{array}{ll}\text { All } & (n=46) \\
\text { Type I } & (n=17) \\
\text { Type II } & (n=29)\end{array}$ & $\begin{array}{l}110(81-166) \\
117(85-166) \\
104(81-140)\end{array}$ & $\begin{array}{l}33.8 \\
35.0 \\
38.7\end{array}$ & $\begin{array}{l}(14.4-75.2) \\
(14.4-53.0) \\
(20.1-75.2)\end{array}$ & $\begin{array}{l}7.17 \\
7.44 \\
7.17\end{array}$ & $\begin{array}{l}(0.9-21.11) \\
(1.21-19.95) \\
(0.9-21.11)\end{array}$ \\
\hline \multicolumn{6}{|c|}{ Diabetic patients with microalbuminuria (urinary albumin excretion $30-200 \mu \mathrm{g} / \mathrm{min}$ ) } \\
\hline $\begin{array}{ll}\text { All } & (n=20) \\
\text { Type I } & (n=7) \\
\text { Type II } & (n=13)\end{array}$ & $\begin{array}{r}80(17-127) \\
109(36-127) \\
72(17-112)\end{array}$ & $\begin{array}{r}81.5 \\
144.3 \\
81.7\end{array}$ & $\begin{array}{l}(48.5-507) \\
(58.8-507) \\
(48.5-192)\end{array}$ & $\begin{array}{l}39.95 \\
39.1 \\
39.6\end{array}$ & $\begin{array}{l}(22-132.5) \\
(24.3-123.2) \\
(22-132.5)\end{array}$ \\
\hline \multicolumn{6}{|c|}{ Diabetic patients with overt albuminuria (urinary albumin excretion $>200 \mu \mathrm{g} / \mathrm{min}$ ) } \\
\hline $\begin{array}{ll}\text { All } & (n=20) \\
\text { Type I } & (n=10) \\
\text { Type II } & (n=10)\end{array}$ & $\begin{array}{l}60(16-175) \\
81(27-175) \\
54(16-82)\end{array}$ & $\begin{array}{r}557 \\
556 \\
1080\end{array}$ & $\begin{array}{r}(26-5782) \\
(26-6782) \\
(114-3908)\end{array}$ & $\begin{array}{l}446 \\
628 \\
546\end{array}$ & $\begin{array}{l}(118-5273) \\
(289-1925) \\
(188-5273)\end{array}$ \\
\hline
\end{tabular}

As intrinsic components of the renal extracellular matrix laminin, collagen IV, and fibronectin were determined in serum and in urine of the patients and the healthy controls. Since none of the quantities tested were different in type I and type II diabetic patients, the results for the two groups are presented together.

\section{Laminin}

The serum concentration and the urinary excretion of laminin was determined. It can be seen that the serum concentrations (fig. 1a) and the urinary excretion (fig. 1b) of this extracellular matrix protein did not change with the progression of renal involvement in diabetes as monitored by the urinary albumin excretion. Further, both quantities were also unaltered in comparison to the control group.

\section{Collagen IV}

Serum concentration of collagen IV (fig. 2a) was diminished in all diabetic patients compared to the control persons $(\alpha<0.01)$.

The urinary excretion of collagen IV is shown in figure $2 \mathrm{~b}$. No detectable amounts of collagen IV could be found in the urine of the control group, whereas $2 \%$ of the normoalbuminuric diabetics, $45 \%$ of the microalbuminuric, and $50 \%$ of the macroalbuminuric patients excreted detectable amounts of collagen IV. The controls and the patients with normal albumin excretion showed no significant difference in collagen IV excretion, while the patients with microalbuminuria and with overt albuminuria excreted significantly higher amounts of this protein $(\alpha<0.001)$.
Serum concentrations and urinary excretion of collagen IV did not correlate to other quantities such as duration of diabetes, $\mathrm{HbA}_{1 \mathrm{lc}}$, creatinine clearance, urinary excretion of protein and albumin.

\section{Fibronectin}

Serum fibronectin was elevated in all diabetic patients $(\alpha<0.0001$; fig. 3a). The determination of urinary fibronectin showed an increased excretion in all diabetic patients compared to the control group ( $\alpha<0.001$; fig. $3 b)$. Serum concentration and urinary excretion of fibronectin did not correlate to the duration of diabetes, $\mathrm{HbA}_{\mathrm{Ic}}$, creatinine clearance, urinary excretion of protein and albumin, and urinary excretion of collagen IV.

To investigate whether the elevated urinary excretion of fibronectin is accompanied by alterations of the pattern of the breakdown products of fibronectin found in urine, additional qualitative studies in the urine by immunoblotting were performed. It was shown that fibronectin was excreted in a distinct, recurrent fragment pattern consisting of two main proteins bands with an apparent relative molecular mass of $M_{\mathrm{r}} 75000$, and 45000 (fig. 4). The fragment pattern was similar in controls and in diabetic patients, independent of the stage of renal involvement in diabetes, and of the type of diabetes. This demonstrates the existence of a very early quantitative but no qualitative change in urinary fibronectin excreted in diabetic patients.

\section{Discussion}

Diabetes induces morphological alterations in the kidney, such as glomerular basementi membrane thickening 

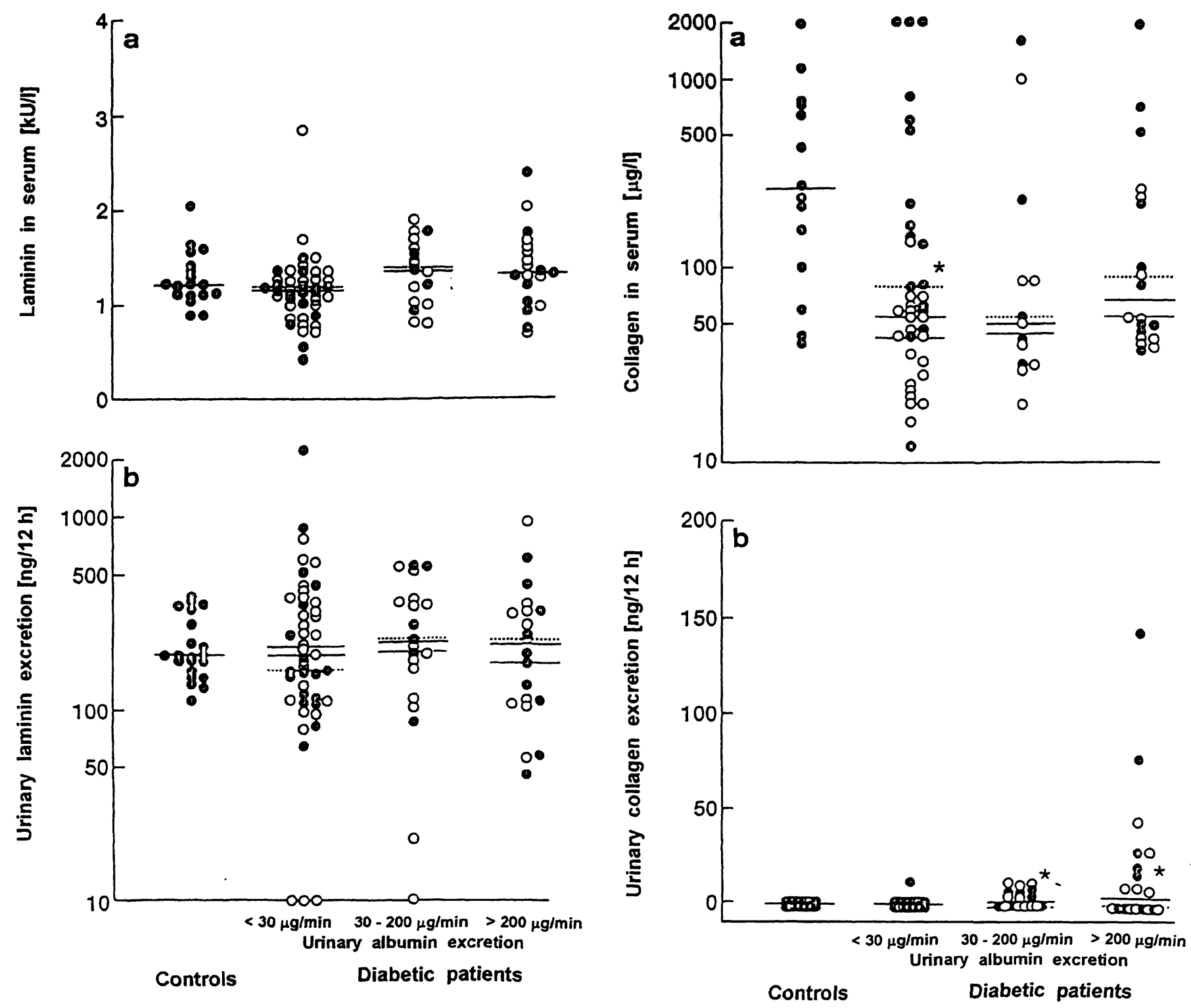

Fig. 1 Serum concentrations (a) and urinary excretion (b) of the laminin P1-fragment in controls and in the diabetic patients.

Controls and type I diabetics: closed circles; type II diabetics: open circles. Horizontal bars represent the medians for the entire group, dashed bars for the type I diabetics, and dotted bars for the type II diabetics.

and expansion of the mesangial matrix, which occurs prior to albuminuria and changes of glomerular filtration rate $(2,20)$. Methods based on the measurement of these functional quantities, routinely used in the diagnosis of diabetic nephropathy, lack the sensitivity required for early detection of the above mentioned structural changes, because the kidney has considerable functional reserves (21). To date, basement membrane thickening and mesangial expansion can only be diagnosed by biopsy, which is not indicated to monitor the renal involvement in diabetes. Therefore, this study was designed to evaluate whether the urinary excretion of extracellular matrix components in diabetic patients might be able to reflect the alterations in renal morphology and the underlying biochemical processes.

Fig. 2 Serum concentration (a) and urinary excretion (b) of collagen IV in controls and in the diabetic patients.

Controls and type I diabetics: closed circles, type II diabetics: open circles. Horizontal bars represent the medians for the entire group, dashed bars for the type I diabetics, and dotted bars for the type II diabetics.

$* a<0.01$

Type I as well as type II diabetic patients were included in this study because both groups are affected by diabetic nephropathy $(5,22-24)$. Since the two groups did not differ significantly with regard to the quantities measured in general, no distinction was made between them in the following discussion.

The extent of renal involvement in diabetes was specified by the urinary albumin excretion since microalbuminuria is currently the most sensitive marker and predictive for the development of diabetic nephropathy (2). Laminin, collagen IV, and fibronectin were determined since these proteins are principal components of the renal extracellular matrix. 

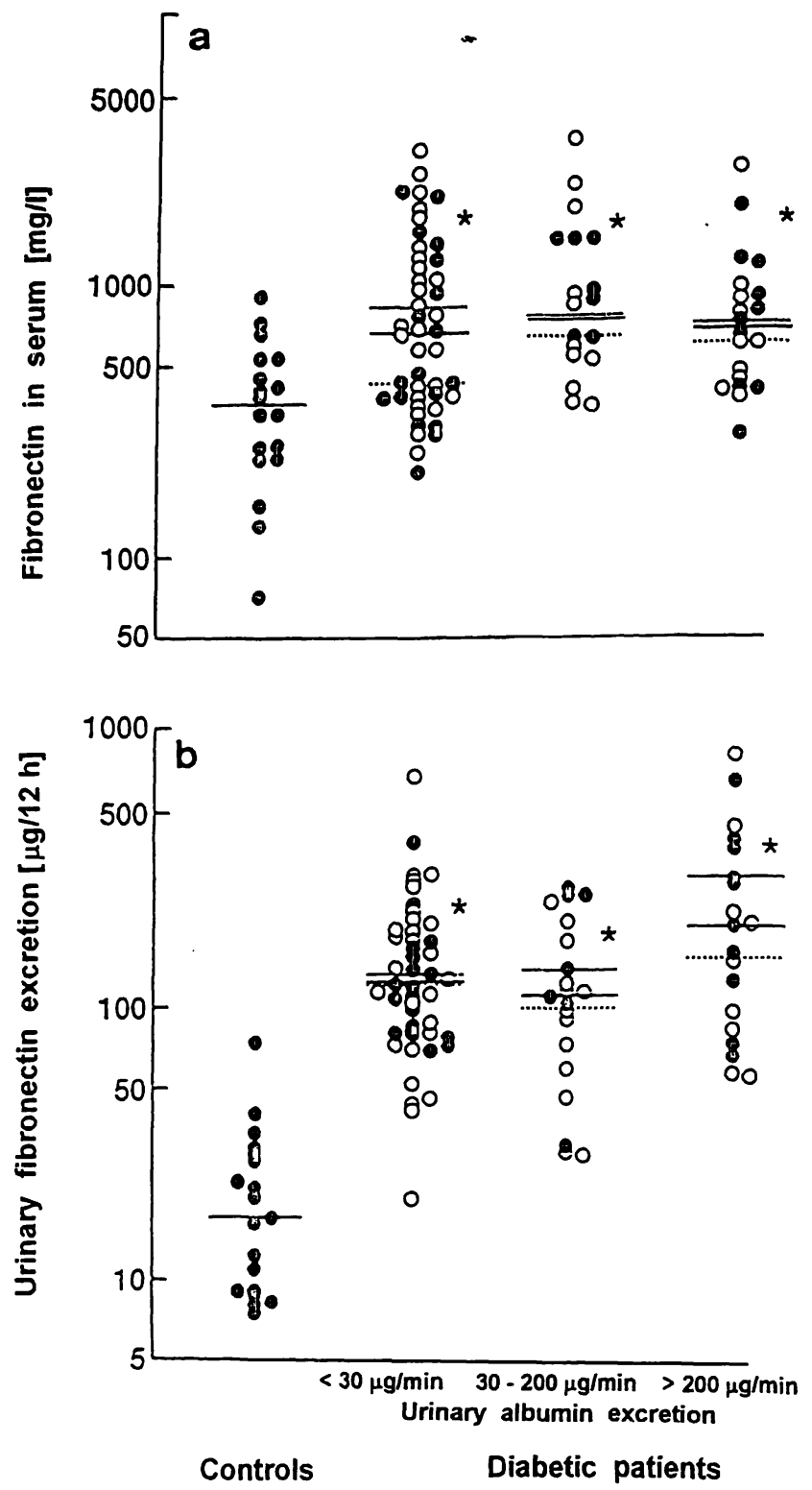

Fig. 3 Serum concentration (a) and urinary excretion (b) of fibronectin in controls and in the diabetic patients.

Controls and type I diabetics: closed circles; type II diabetics: open circles. Horizontal bars represent the medians for the entire group, dashed bars for the type I diabetics, and dotted bars for the type II diabetics.

$* \alpha<0.01$

Laminin, measured as laminin P1-fragment, is predominantly localized at the endothelial site of the laminae rarae, where it is responsible for cell attachment and probably contributes, besides the proteoglycans, to the charge selectivity of the basement membrane $(25,26)$. Immunohistochemical studies by Falk et al. (6) showed an increase of laminin in the glomerular and tubular basement membrane, and in the mesangial matrix in early and moderate diabetic nephropathy, whereas the content of this protein was decreased in severe nephropathy. Shimomura et al. (27) and Karttunen et al. (28) found a decreased laminin concentration in the diabetic basement membrane by biochemical methods. No significant difference in serum laminin concentrations and in the urinary excretion of this protein was found between the diabetic patients and the control persons in this study. The slight increase of the laminin P1-fragment in the serum of diabetic patients, as described by Hoegemann et al. (29), could not be confirmed. The results of the present study indicate that the laminin concentration in serum and in urine is independent of the stage of diabetic nephropathy, and that laminin excretion in urine is not able to reflect the changes this protein underlies in the diabetic kidney.

Collagen IV, which provides a resilient three-dimensional network forming the backbone of the glomerular basement membrane, is another important constituent of the renal extracellular matrix determined in this study $(30-32)$. In the diabetic kidney, changes in the metabolism of collagen IV are principally responsible for the thickening of the glomerular basement membrane $(6,8$, 33). The metabolic disorders lead to an increased synthesis of this protein and further to a decreased degradation which results in an accumulation of collagen IV in the glomerular basement membrane (34-36). The determination of collagen IV in serum showed significantly decreased concentrations in the diabetic patients in comparison to controls. This is in contrast to findings of others, who found an increased serum concentration of collagen IV in diabetic patients $(29,37)$ or no alterations (12). The decreased serum concentration of collagen IV found in the present study is interpreted as a consequence of the decreased degradation of this pro-

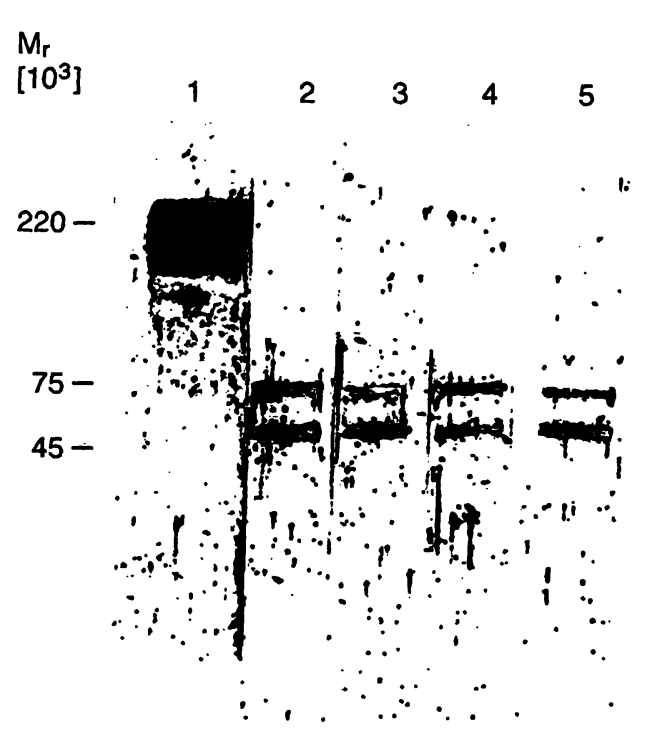

Fig. 4 Representative immunoblot of the urinary fragment pattern of fibronection.

Lane 1: purified human plasma fibronectin,

lane 2: urine of a control person,

lane 3: urine of a patient with normal albumin excretion $(<30$ $\mu \mathrm{g} / \mathrm{min}$ ),

lane 4: urine of a patient with microalbuminuria (urinary excretion $30-200 \mu \mathrm{g} / \mathrm{min}$ ),

lane 5: urine of a patient with overt albuminuria (urinary excretion $>200 \mu \mathrm{g} / \mathrm{min}$ ). 
tein in nearly all basement membranes. The urinary excretion of collagen was significantly increased in patients with microalbuminuria and with overt albuminuria. This is in agreement with findings of Torffuit et al. (12), who additionally found a decreased urinary excretion of collagen IV in advanced diabetic nephropathy. The results show that the determination of collagen in urine is able to reflect the alterations of this protein in the diabetic kidney. It is suggested that the destruction of the glomerular basement membrane in the course of the progressing glomerular sclerosis is responsible for the elevated urinary excretion of this protein. But since the collagen IV excretion raises in parallel to the albumin excretion, its determination in final urine yields no additional information to the quantitites routinely used.

Fibronectin, as an intrinsic component of the renal extracellular matrix, was also determined. This protein is predominantly localized in the mesangial matrix $(7,26,38)$. It is produced by mesangial and endothelial cells as well as by pericytes $(39,49,41)$. Fibronectin found in the glomerular basement membrane is supposed to be trapped from plasma and not to be of renal origin (25, $30,31)$. In diabetes an accumulation of fibronectin in the mesangial matrix was shown in mild to moderate diabetic nephropathy, while the content of this protein was decreased in sclerotic glomeruli $(6,7)$.

In the present study fibronectin was increased in the serum of all diabetic patients, even in those with normal urinary albumin excretion. Other studies showed inconsistent results. Labat-Robert et al. (42) found a decreased plasma fibronectin concentration in diabetics whereas Degiorgio et al. (43) reported increased concentration in patients with retinopathy and microalbuminuria. Davis et al. (44) could not find any difference in serum fibronectin content in diabetic and non-diabetic persons.

The urinary fibronectin excretion was elevated prior to the onset of microalbuminuria. This could coincide with the accumulation of this protein in the mesangial matrix in early and moderate diabetic nephropathy $(6,7)$ and, thus, reflect the impaired fibronectin metabolism in the diabetic kidney.

Since the urinary excretion of fibronectin seems to be valuable in assessing the early involvement of the kidney in diabetes, it was studied not only quantitatively but also qualitatively by immunoblotting. The protein was excreted in a distinct fragment pattern of two main bands with an apparent relative molecular mass of $M_{\mathrm{r}} 75000$, and 45000 in the urine of control persons and of diabetic patients at different stages of nephropathy. The unaltered and recurring fragment pattern indicates that these fragments are products of a defined turnover of fibronectin in the kidney. Its quantitatively elevated excretion in parallel to its unchanged qualitative excretion suggests an inbalanced turnover in diabetes.

Metabolic and micropuncture experiments in rats demonstrated that the urinary fibronectin fragments originate from the glomeruli and that the fragment pattern is not altered during tubular passage. Serum fibronectin is found in final urine only in cases of severe glomerular damage, when high molecular mass plasma proteins are allowed to permeate the glomerular filter $(45,46)$.

From the results of the present study the following cascade of events is hypothesized. The accumulation of extracellular matrix proteins is probably due to the high glucose concentration in the tissue, which is supposed to stimulate the protein synthesis and to diminish the protein degradation $(48-50)$. The non-enzymatic glycation of the proteins, and the formation of oxygen radicals are the suggested mechanisms through which glucose causes these biochemical alterations $(51-54)$. The expanding mesangium, which compresses the capillary vasculature and ultimately leads to glomerular closure, is thought to be the primary cause for the development of diabetic nephropathy rather than the loss of the charge and size selectivity of the glomerular filtration barrier $(4,55)$.

\section{Conclusion}

We show in this study that

(1) the changes laminin undergoes in diabetes are not reflected by its urinary excretion,

(2) collagen IV excretion is elevated in parallel to the occurrence of microalbuminuria and probably reflects the decline of the glomerular basement membrane,

(3) urinary fibronectin is elevated in diabetic patients prior to functional restrictions and probably reflects the mesangial expansion due to the accumulation of extracellular matrix proteins probably caused by increased glucose concentration in the tissue.

With regard to these findings, urinary fibronectin excretion may serve as an early marker for the renal involvement in diabetes, but further studies are necessary to substantiate this assumption. 


\section{References}

1. Mauer SM, Ellis EN, Bilous RW, Steffes MW. The pathology of diabetic nephropathy. Transplant Proc 1986; 18:1629-31.

2. Mogensen CE. Microalbuminuria as a predictor of clinical diabetic nephropathy. Kidney Int 1987; 31:573-89.

3. Osterby R, Parving HH. Hommel E, Jorgensen HE, Lokkegaard $\mathrm{H}$. Glomerular structure and function in diabetic nephropathy. Early to advanced stage. Diabetes 1990; 39:1057-63.

4. Mauer SM, Steffes MW, Ellis EN, Sutherlands DER, Brown DM. Goetz FC. Structural-functional relationship in diabetic nephropathy. J Clin Invest 1984; 74:1143-55.

5. Schleicher E. Nerlich A, Gerbitz KD. Pathobiochemical aspects of diabetic nephropathy. Klin Wochenschr 1989; 66:873-82.

6. Falk RJ, Scheinmann JI, Mauer SM, Michael AF. Polyantigenic expansion of basement membrane constituents in diabetic nephropathy. Diabetes 1983; 32 Suppl 2:34-9.

7. Dixon AJ, Burns J, Dunnill MS, McGee J. Distribution of fibronectin in normal and diseased human kidneys. J Clin Pathol 1980; 33:1021-8.

8. Sternberg M, Cohen-Forterre L, Peyroux J. Connective tissue in diabetes mellitus: biochemical alterations of the intercellular matrix with special reference to proteoglycans, collagens and basement membranes. Diab Metabol 1985; 11:27-50.

9. Kanwar YS, Rosenzwveig LJ, Linker A, Jakubowski ML. Decreased te novo synthesis of glomerular proteoglycans in diabetes: biochemical and autoradiographic evidence. Proc Natl Acad Sci USA 1983; 80:2272-5.

10. Weil R, Nozawa M, Koss M, Weber C, Reemtsma K, McIntosh R. The kidney in streptozotocin diabetic rats. Arch Pathol Lab Med 1976; 100:37-49.

11. Mellon CD, Sasser BM, Bowman BH. Increased concentrations of basement membrane collagen fragment in urine of diabetic mice. Biochem Gen 1985; 22:631 -9.

12. Torffvit O, Agardh CD, Cederholm B, Wieslander J. A new enzyme-linked immunosorbent assay for urine and serum concentrations of the carboxyterminal domain (NC1) of collagen IV. Application in type I (insulin-dependent) diabetes. Scand J Clin Lab Invest 1989; 49:431-9.

13. Bradford MM. A rapid and sensitive method for the quantitation of microgram quantities of protein utilizing the principle of protein-dye binding. Anal Biochem 1976; 72:248-54.

14. Laurell CB. Quantitative estimation of proteins by electrophoresis in agarose gel containing antibodies. Anal Biochem 1966; $15: 45-52$

15. Cole RA, Soeldner JS, Dunn PJ, Bunn HF. A rapid method for the determination of glycosylated hemoglobins using high pressure liquid chromatography. Metabolism 1978; 27:289.

16. Avrameas S. Coupling of enzymes to proteins with glutaraldehyde. Immunochemistry 1969;6:43.

17. Engvall E. Fibronectin. In: Bergmeyer HU, editor. Methods of enzymatic analysis. Weinheim: VCH Weinheim, 1986:201-11.

18. Khyse-Andersen J. Semidry electroblotting - transfer using equipment without buffer vessel. In: Bjerrum OJ, Heegaard $\mathrm{NHH}$, editors. Handbook of immunoblotting of proteins. Boca Raton: CRC Press Inc., 1988:79-85.

19. Blake MS, Johnston KH, Russell-Jones GJ, Gotschlich EC. A rapid sensitive method for detection of alkaline phosphataseconjugated anti-antibody on western blots. Anal Biochem $1984 ; 136: 175-9$.

20. Osterby R, Gundersen HJG, Nyberg G, Aurell M. Advanced diabetic glomerulopathy: quantitative structural characterization of nonoccluded glomeruli. Diabetes 1987; 36:612-9.

21. Mantle D. Lauffert B, McDermott J, Gibson A. Characterization of aminopeptidase in human kidney soluble fraction. Clin Chim Acta 1990; 187:105-14.

22. Schmitz A, Gundersen HJG, Osterby R. Glomerular morphology by light microscopy in non-insulin-dependent diabetes mellitus. Diabetes 1988; 37:38-43.
23. Hasslacher C, Ritz E, Wahl P, Michael C. Similar risks of nephropathy in patients with type I or type II diabetes mellitus. Nephrol Dial Transplant 1989; 4:859-63.

24. Viberti GC. Etiology and prognostic significance of albuminuria in diabetes. Diabetes Care 1988; 11:840-5.

25. Hayman EG, Oldberg A, Martin GR, Ruoslahti E. Codistribution of heparan sulfate proteoglycan, laminin, and fibronectin in the extracellular matrix of normal rat kidney cells and their coordinate absence in transformed cells. J Cell Biol 1982; 94:28-30.

26. Madrid JA, Roll FJ, Furthmayr H, Foidart JM. Ultrastructural localization of fibronectin and laminin in the basement membrane of the murine kidney. J Cell Biol 1980; 86:682-7.

27. Shimomura H, Spiro RG. Studies on macromolecular components of human glomerular basement membrane and alterations in diabetes. Diabetes $1987 ; 36: 374-81$.

28. Karttunen T, Risteli J, Autio-Harmainen H, Risteli L. Effect of age and diabetes on Type IV collagen and laminin in human kidney cortex. Kidney Int 1986; 30:586-91.

29. Högemann B, Balleisen L, Rauterberg J, Voss B, Gerlach U. Basement membrane components ( $7 \mathrm{~S}$ collagen, laminin $\mathrm{P} 1$ ) are increased in sera of diabetics and activates platelets in vitro. Haemostasis $1986 ; 16: 428-32$.

30. Martinez-Hernandez A, Amenta PS. The basement membrane in pathology. Lab Invest 1983; 48:656-77.

31. Leblond CP, Inoue S. Structure, composition, and assembly of basement membranes. Am J Anatomy 1989; 185:367-90.

32. Yurchenco PD, Schittny JC. Molecular architecture of basement membranes. FASEB J 1990; 4:1577-90.

33. Mohan PS, Carter WG, Spiro RG. Occurence of type IV collagen in extracellular matrix of glomeruli and its increase in diabetes. Diabetes 1990; 39:31-7.

34. Cohen MP, Surma M. Renal glomerular basement membrane: in vivo biosynthesis and turnover in normal rats. $\mathrm{J}$ Biol Chem 1980; 255:1767-70.

35. Brownlee M, Spiro RG. Glomerular basement membrane metabolism in the diabetic rat. In vivo studies. Diabetes 1979; 28:121-5.

36. Hasslacher C, Reichenbacher R, Gechter F, Timpl R. Glomerular basement membrane synthesis and serum concentration of type IV collagen in streptozotocin-diabetic rats. Diabetologia 1984; 26:150-4.

37. Matsumoto E, Matsumoto G, Ooshima A, Kikuoka H, Bessho H, Miyamura K, Nanjo K. Serum type IV collagen concentrations in diabetic patients with microangiopathy as determined by enzyme immunoassay with monoclonal antibodies. Diabetes 1990; 39:885-90.

38. Courtoy PJ, Timpl R, Farquhar MG. Comparative distribution of laminin, type IV collagen, and fibronectin in the rat glomerulus. J Histochem Cytochem 1982; 30:874-86.

39. Hawkins NJ, Wakefield D, Charlesworth JA. The role of mesengial cells in glomerular pathology. Pathology 1990; 22:24-32.

40. Oberley TD, Mosher DF, Mills MD. Localization of fibronectin within the renal glomerulus and its production by cultured glomerular cells. Am J Pathol 1979; 96:651-62.

41. Foidart JM, Foidart JB, Mahieu PR. Synthesis of collagen and fibronectin by glomerular cells in culture. Renal Physiol 1980; 3:183-92.

42. Labat-Robert J, Leutenegger M, Llopis G, Ricard Y, Deroutte JC. Plasma and tissue fibronectin in diabetes. Clin Physiol Biochem 1984; 2:39-48.

43. DeGiorgio LA, Martolomei G, Gironi A, Caselli P, Seghieri G. Increased plasma fibronectin concentration in diabetic patients with albuminuria. Diabetes Care 1988; 11:527-30.

44. David TME, Moore JC, Turner RC. Plasma fibronectin, factor VIII-related antigen and fibrinogen concentrations, and diabetic retinopathy. Diabete \& Metabolisme 1985; 11:147-51.

45. Soose M, Gwinner W, Grotkamp J, Hansemann W, Stolte H. Altered renal fibronectin excretion in early adriamycin nephrosis in rats. J Pharmacol Exp Ther 1991; 257:493-9. 
46. Gwinner W, Jäckle-Meyer I, Stolte $H$. Origin of urinary fibronectin. Lab Invest 1993; 69:250-5.

47. Soose $M$, Wenzel S, Oberst D, Stolte H. Fibronectin turnover in human mesangial cell cultures as affected by adriamycin. Cell Biol Toxicol 1993; 3:149-53.

48. Ayo SH, Radnik RA, Garoni JA, Glass WF, Kreisberg JI. High glucose causes an increase in extracellular matrix proteins in cultured mesangial cells. Am J Pathol 1990; 136:1339-48.

49. Kreisberg Jl, Radnik RA, Ayo SH, Garoni J, Saikumar P. High glucose elevates c-fos and c-jun transripts and proteins in mesangial cell cultures. Kidney Intern 1994; 46:105-12.

50. Cagliero E, Maiello M. Boeri D, Roy S, Lorenzi M. Increased expression of basement membrane component in human endothelial cells cultured in high glucose. J Clin Invest 1988; 82:735-8.

51. Lubec G, Pollak A. Reduced susceptibility of nonenzymatically glycosylated glomerular basement to proteases: is thickening of diabetic glomerular basement membranes due to reduced proteolytic degradation? Renal Physiol 1980; 3:4-8.

52. Hunt JV, Dean RT, Wolff SP. Hydroxyl radical production and autoxidative glycosylation. Biochem J 1988; 256:205-12.
53. Gillery P, Monboisse JC, Maquart FX, Borel JP. Does oxygen free radical increased formation explain long term complications in diabetes mellitus? Medical Hypothesis 1989; 29:4750.

54. Reicherd P, Nilsson BY, Rosenqvist U. The effect of long-term intensified insulin treatment on the development of microvascular complications of diabetes mellitus. N Engl J Med 1993; 329:977-86.

55. Williamson JR, Tilton RG, Chang K, Kilo C. Basement membrane abnormalities in diabetes mellitus: relationship to clinical microangiopathy. Diabetes/Metabolism Reviews 1988; 4:339-70.

Dr. Irmtrud Jäckle-Meyer

Medizinische Hochschule Hannover

Zentrum Innere Medizin und Dermatologie

Abteilung für Nephrologie

Arbeitsbereich Experimentelle Nephrologie

Konstanty-Gutschow-Straße 8

D-30625 Hannover

Germany 
